\title{
The fine spatial and temporal control of ultrasonic neuromodulation is a necessary condition for discerning the accompanying subjective feelings, but is it sufficient?
}

\section{Robert Muratore (D)}

"...one man can give birth to the elements of an art, but only another can judge how they can benefit or harm those who will use them." - Plato, Phaedrus 274 e

Engineering models of biological systems can lead to better understanding and manipulation of those systems. The mechatronics systems model closely parallels the human nervous system [1]; the electromechanical feedback loops can be used to model the many biological arcs. Anatomy and physiology texts typically divide the nervous system into receptors, the sensory division of the peripheral nervous system, the central nervous system, the somatic and autonomic subdivisions of the motor division of the peripheral nervous system, the effectors, and, implicitly, the outside world. Guided by the mechatronics viewpoint on this ur-system, external, engineered energies (such as those available from electric, magnetic, and acoustic fields) can be injected directly into any stage of the nervous system loop. Thus it is possible to stimulate receptors in novel ways [2, 3], or to directly stimulate an upstream stage, bypassing the sensory apparatus $[4,5]$.

Such an injection of energy into the nervous system is an encompassing definition of neuromodulation $[6,7]$. At low doses, neuromodulation is safe enough for consumer use, with commercially available low voltage direct current devices [8]. Subjective perceptions of such neuromodulation are subtle and muted, perhaps even lost in the thermal noise of the chemical processes that constitute thought [9].

Ultrasound has certain advantages as a neuromodulation modality, with finer spatial and temporal control compared to electromagnetic approaches [10] (offset by

Correspondence: wave@quantumnow.com

Quantum Now LLC, Huntington, New York, USA disadvantages such as the need for a coupling medium, the calculations needed to account for field distortions from the skull transit [11], and FDA strictures [12]).

The millimetre and millisecond resolution of ultrasonic neuromodulation matches important brain structures and functions and therefore could elicit clearer subjective phenomena. How could these phenomena be described?

Stimulus to a sensory cortex region is likely to be interpreted as the sense associated with that area. For example, stimulus to the tonotopic area of auditory cortex [13] would presumably result in a hearing sensation. If so, a sufficiently focused and lively ultrasound beam could "play" a tune by ranging over the tonotopic region.

More generally, traditional subjective measures of sensory phenomena [14] can provide some guidance, as can rigorous psychophysical methods for estimating thresholds and just noticeable differences [15].

However, these approaches might be challenging for stimuli outside of sensory regions if there is no vocabulary for the subjects and no set of previous experiences with which to compare. Even when words and images are available, certain subjective experiences, such as dreams, can elude rational description. Synesthesia is a possibility, mapping the new sensations onto existing sensory interpretations, but is it also possible to develop a new sense?

The brain plasticity required for the development of such a sense would require some learning in order to build up the necessary connections [16]. The brain has been shown to reroute around damaged regions in the hearing centre, and there is evidence of plasticity in the adult brain due to external stimulus [17].

Insofar as neuromodulation represents an external source that influences the brain, it can be considered to be the source of new, artificial senses $[18,19]$. Each 
of the natural senses has highly developed cultural associations [20], and each sense has been amplified by technology. Artists have been at the forefront, almost by definition of their calling, of the interaction of the sensory amplification technologies and the cultural implications [21].

So how then can the possible new sensations be discerned? How can they be defined, and connected together to form feedback loops and networks embodying ideas of interest and of value? This is a role that artists can play. If a safe, effective neuromodulation apparatus could be provided, collaboration between bioengineers and artists can help to define the new neuromodulated perceptions.

\section{Author's contribution}

The author wrote, read and approved the final manuscript.

\section{Competing interests}

The author is an inventor on one of the cited patents, and has no additional competing interests.

\section{Publisher's Note}

Springer Nature remains neutral with regard to jurisdictional claims in published maps and institutional affiliations.

Received: 12 November 2018 Accepted: 14 November 2018

\section{Published online: 23 November 2018}

\section{References}

1. Lee MH, Nicholls HR. Tactile sensing for mechatronics - a state of the art survey. Mechatronics. 1999;9:1-31.

2. Gavrilov LR. Use of focused ultrasound for stimulation of various neural structures. New York: Nova; 2014

3. Muratore R, Vaitekunas JJ. Ultrasonic bioeffects on peripheral nerves. Acoustics Today. 2012;8(4):38-42.

4. Dawson TP. Method and system for generating sensory data onto the human neural cortex. US Patent 006536440 B1, assigned to Sony Corp; 2003.

5. Muratore R, LaManna J, Lamprecht M, Morrison B. Bioeffects of Low Dose Ultrasound on Neuronal Cell Function. In: Hodnett M, Muratore R, editors. Proceedings of the 38th Annual Ultrasonic Industry Association Symposium. Vancouver: IEEE Xplore; 2009

6. Krames ES, Peckham PH, Rezai AR, editors. Neuromodulation. Cambridge: Academic Press; 2009.

7. Lewis PM, Thomson RH, Rosenfeld JV, Fitzgerald PB. Brain neuromodulation techniques: a review. Neuroscientist. 2016;22(4):406-21.

8. National Academies of Sciences, Engineering, and Medicine. Non-invasive neuromodulation of the central nervous system: opportunities and challenges: workshop summary. Washington, DC: The National Academies Press; 2015.

9. Schrodinger E. What is life? The physical aspect of the living cell. New York: Cambridge University Press; 1944

10. Tufail Y, Yoshihiro A, Pati S, Li MM, Tyler WJ. Ultrasonic neuromodulation by brain stimulation with transcranial ultrasound. Nat Protoc. 2011:6:1453-70.

11. White PJ, Clement GT, Hynynen K. Longitudinal and shear mode ultrasound propagation in human skull bone. Ultrasound Med Biol. 2006:32(7):1085-96.

12. Wear K (2018) CDRH Research Programs: Ultrasonics Laboratory https:// www.fda.gov/MedicalDevices/ScienceandResearch/ucm477417.htm. Updated September 27, 2018. Accessed 6 Nov 2018.

13. Romani GL, Williamson SJ, Kaufman L. Tonotopic organization of the human auditory cortex. Science. 1982;18:1339-40

14. Flynn JE, Hendrick C, Spencer T, Martyniuk O. A guide to methodology procedures for measuring subjective impressions in lighting. J Illum Eng Soc. 1979:8(2):95-110.

15. Stevens S. Psychophysics. New York: Routledge; 1986.

16. Muratore R, Zee DS. Pursuit after-nystagmus. Vis Res. 1979;19(9):1057-9.

17. Fraser C, Power M, Hamdy S, Rothwell J, Hobday D, Hollander I, Tyrell P, Hobson A, Williams S, Thompson D. Driving plasticity in human adult motor cortex is associated with improved motor function after brain injury Neuron. 2002:3(5):831-40.

18. Tyler WJ, Tufail Y, Finsterwald M, Tauchmann ML, Olson EJ, Majestic C Remote excitation of neuronal circuits using low-intensity, low-frequency ultrasound. PLoS One. 2008;3(10):e3511.

19. Tyler WJ, Goldwasser I, Muratore R, Pal S, Sato T, Wetmore DZ (2015) Method and system for direct communication. US Patent 9,042,201.

20. Thierry G, Athanasopoulos P, Wiggett A, Dering B, Kuipers JR. Unconscious effects of language-specific terminology on preattentive color perception. Proc Natl Acad Sci. 2009;106(11):4567-70.

21. Shillito AM, Paynter K, Wall S, Wright M. 'Tacitus' project: identifying multi-sensory perceptions in creative 3D practice for the development of a haptic computing system for applied artists. Digit Creativity. 2001; 12(4):195-204.
Ready to submit your research? Choose BMC and benefit from:

- fast, convenient online submission

- thorough peer review by experienced researchers in your field

- rapid publication on acceptance

- support for research data, including large and complex data types

- gold Open Access which fosters wider collaboration and increased citations

- maximum visibility for your research: over $100 \mathrm{M}$ website views per year

At $\mathrm{BMC}$, research is always in progress.

Learn more biomedcentral.com/submissions 